\title{
Trust and the Reference Points for Trustworthiness in Gulf and Western Countries
}

\section{Citation}

Bohnet, Iris, Benedikt Herrmann, and Richard Zeckhauser. 2010. Trust and the Reference Points for Trustworthiness in Gulf and Western Countries. Quarterly Journal of Economics 125(2):

811-828.

\section{Published Version}

http://dx.doi.org/10.1162/qjec.2010.125.2.811

\section{Permanent link}

http://nrs.harvard.edu/urn-3:HUL.InstRepos:9647371

\section{Terms of Use}

This article was downloaded from Harvard University's DASH repository, and is made available under the terms and conditions applicable to Open Access Policy Articles, as set forth at http:// nrs.harvard.edu/urn-3:HUL.InstRepos:dash.current.terms-of-use\#OAP

\section{Share Your Story}

The Harvard community has made this article openly available.

Please share how this access benefits you. Submit a story.

Accessibility 
Forthcoming: Quarterly Journal of Economics

\title{
TRUST AND THE REFERENCE POINTS FOR TRUSTWORTHINESS IN GULF AND WESTERN COUNTRIES ${ }^{\#}$
}

\author{
Iris Bohnet ${ }^{*}$ \\ Benedikt Herrmann $^{* *}$ \\ and Richard Zeckhauser ${ }^{*}$
}

Why is private investment so low in Gulf compared to Western countries? We investigate crossregional differences in trust and reference points for trustworthiness as possible factors. Experiments controlling for cross-regional differences in institutions and beliefs about trustworthiness reveal that Gulf citizens pay much more than Westerners to avoid trusting, and hardly respond when returns to trusting change. These differences can be explained by subjects' gain/loss utility relative to their region's reference point for trustworthiness. The relation-based production of trust in the Gulf induces higher levels of trustworthiness, albeit within groups, than the rule-based interactions prevalent in the West.

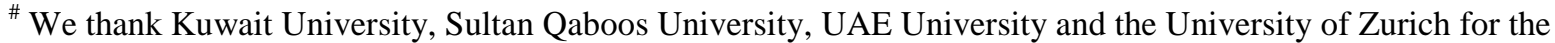
permission to conduct our research, and Samar Attar, Miriam Avins, Paul Bohnet, Robin Hogarth, Sarah Hrdy, Magda Ismail, Timur Kuran, Alan Levy, Stephan Meier, Hilary Rantisi, Dani Rodrik Frank Vogel, three anonymous referees, the participants in seminars at Harvard, Pompeu Fabra University (Barcelona), the University of Zurich, the Santa Fe Institute, the conference for Laboratory Experiments and the Field (University College London), the CESifo conference on Economics and Psychology (Venice), and the Economic Science Association Meetings 2005 (Montreal), and particularly Edward Glaeser (the editor) for their helpful comments. Financial support from the Kuwait Fund at Harvard Kennedy School and the U. S. Army Research Laboratory and the U. S. Army Research Office under grant number W911NF-08-1-0144 is gratefully acknowledged.
} 


\section{Introduction}

Private domestic investment is low in Arab countries, particularly relative to public investment. In the Persian Gulf countries examined here, the private/public ratio was less than 2 in the 1990s, for OECD countries it was over 6 [Sala-i-Martin and Artadi 2002]. Investment requires placing one's funds in the hands of another person. Not surprisingly, investment rates are closely associated with people's willingness to trust others [Knack and Keefer 1997]. Trust levels are generally low in Islamic societies. Across the fourteen Islamic countries surveyed in the World Values Survey, only 28 percent of the respondents indicated that "most people can be trusted," compared to 46 percent in Protestant European countries [Inglehart 2007]. ${ }^{1}$

We investigate whether reference points for trustworthiness help explain these crossregional differences in people's willingness to trust strangers. We build on Kahneman and Tversky's [1979] Prospect Theory and the formalizations by Köszegi and Rabin [2006, 2007], and posit that betrayal imposes an additional utility cost beyond monetary loss. That cost increases the more the likelihood of betrayal deviates from one's reference points of accustomed experience.

Gulf residents are accustomed to higher levels of trustworthiness than Westerners. As is typical for tribal societies, most trust interactions take place within groups. Trust is fostered by decreasing the likelihood of betrayal through repeated interactions, reputation and reciprocity. "Aman [i.e., trust] ... tends to convey a sense of personal attachment between those who trust one another rather than confidence in institutions, office-holders, or even one's own knowledge or abilities.... For Arabs, who believe that it is contexts of relationship, not invariant capabilities, that most fully define a person, actively entangling them in webs of indebtedness

\footnotetext{
${ }^{1}$ Interpersonal trust and more generally what Inglehart [2007] refers to as "self-expression values" have also been associated with support for democracy.
} 
constitutes the greatest predictability and security that one can have for their actions towards oneself.” [Rosen 2000, p. 135-136]. Social networks have evolved to allow for such informal enforcement: "Groups in the Middle East are necessarily more limited in size in order to maximize trust and cooperative endeavor... Asabiyya ["social solidarity"] was most easily developed in small, informal, and highly personalistic groups." [Bill and Springborg 2000, p. 66-67]. Untrustworthy behavior often leads to expulsion, and xenophobia is common [e.g., Arab Human Development Report 2004; Inglehart et al. 2006]. ${ }^{2}$

In the West, by contrast, formal institutions, notably contract law, promote trust by decreasing the cost of betrayal by awarding damages given breach. Oliver Wendell Holmes Jr. wrote about US law in 1897: "The duty to keep a contract at common law means a prediction that you must pay damages if you do not keep it and nothing else." [Rosen 2000, p. 139]. ${ }^{3}$

Given the differences in their trustworthiness reference points, people in the Gulf will demand higher levels of trustworthiness before trusting than Westerners. To examine experimentally, we elicit people's minimum acceptable probability of trustworthiness, the threshold value that would make them just willing to trust a randomly selected, anonymous counterpart, given particular payoffs, in three Gulf countries, Kuwait, Oman and the United Arab Emirates, and two Western countries, Switzerland and the United States. The higher a person's threshold, the higher the price — in loss of expected value of payoff — she is willing to

\footnotetext{
${ }^{2}$ The Economist [April 9, 2005, p. 37] describes a recent case in Qatar where "its rulers have just stripped some 5,000 Qataris of their citizenship, apparently because they belong to a clan deemed disloyal." Cultural theorists characterize the Gulf countries as "collectivist" and Protestant Western countries as "individualist" countries [e.g., Triandis 1995; Hofstede 2001]. They predict a stronger distinction between "in-group" and "out-group" members in the former than the latter. See also Greif [1994] and Kuran [2004].

${ }^{3}$ In Islamic Law, contracts that impose expectations on future performance are not permitted because they are inherently speculative [Rosen 2000, p. 142]. Specifically, there is no recovery for lost profits or other damages that are based on a counter-factual premise or speculation about events that did not occur [Vogel 1987].
} 
pay to avoid trusting. Our method eliminates institutional factors and beliefs about a counterpart's trustworthiness as explanations. To control for differences in willingness to take risk, we elicit minimum acceptable probabilities for a straight gamble offering the same payoffs for the two parties as the trust game. The difference in values for the required probabilities when confronted with nature rather than a person isolates a person's intolerance of betrayal.

The utility structure we posit creates a second effect. It affects how responsive people are to changes in the likelihood or the cost of betrayal. We label the way people respond to changes in the expected returns from trusting as their elasticity of trust, and calibrate it using our experiments. Elasticity of trust must be high if institutional innovations, such as laws that protect investors or enforce contracts, are to raise trust and investment. Our paper is organized as follows. Part II presents our theory and conceptual framework. Part III explains the experimental design, and Part IV presents the results. Part V concludes.

\section{Theory and Methods}

Trust is primarily produced by preventing betrayal through webs of relationships in the Gulf, but by mitigating the cost of betrayal through contract law in the West. This difference leads to differences in accustomed levels of trustworthiness in the two regions. We posit that such trustworthiness experiences provide a reference point, $r$, for expectations of trustworthiness levels, $r_{g}$ and $r_{w}$, respectively in the Gulf and Western nations, where $r_{g}>>r_{w}$. We build on a model of reference-dependent preferences by Köszegi and Rabin [2006], who argue that individuals experience a loss aversion component when an outcome deviates from a reference point that is "endogenously determined by the economic environment, derived from experiences in the past" [p. 1133]. 
Consider two groups of individuals who must choose between lotteries S and T, Sure and Trust. A lottery pays $\mathrm{x}$ with probability $\mathrm{p}$ and $\mathrm{y}<\mathrm{x}$ with probability $1-\mathrm{p}$. The total utility function is

$$
\mathrm{u}(\mathrm{p}, \mathrm{r}, \mathrm{x}, \mathrm{y})=\mathrm{pv}(\mathrm{x})+(1-\mathrm{p}) \mathrm{v}(\mathrm{y})+\mathrm{z}(\mathrm{p}, \mathrm{r}, \mathrm{x}, \mathrm{y}) .
$$

Here $\mathrm{v}$ is a traditional vonNeumann-Morgenstern $(\mathrm{VN}-\mathrm{M})$ utility function, where $\mathrm{v}^{\prime}>0$. The innovation beyond traditional utility theory is that $\mathrm{z}(\mathrm{p}, \mathrm{r}, \mathrm{x}, \mathrm{y})$ is a reference-dependent utility coming from the probability of trustworthiness itself.

For $\mathrm{T}, 0<\mathrm{p}<1, \mathrm{x}=\mathrm{m}$ and $\mathrm{y}=\mathrm{n}<\mathrm{m}$. For $\mathrm{S}, \mathrm{p}=1, \mathrm{x}=\mathrm{s}$, and the value of $\mathrm{y}$ is irrelevant. For the choice to be meaningful, $\mathrm{m}>\mathrm{s}>\mathrm{n}$. Consistent with Koszegi and Rabin (and intuition), we assume that $\mathrm{z}$ is increasing with $\mathrm{p}$ and strictly decreasing with $\mathrm{r}$. This implies that $\mathrm{u}$ is increasing with $\mathrm{p}$. For $\mathrm{p}=0$, $\mathrm{T}$ is inferior to $\mathrm{S}$; at $\mathrm{p}=1$ it is superior. Since the utility of $\mathrm{S}$ does not vary with $\mathrm{p}$, there must be a minimum cutoff value $\mathrm{p}_{\mathrm{j}}$ that makes an individual $\mathrm{j}$ willing to trust. In particular, $\mathrm{p}_{\mathrm{j}}$, sets $u(S)=u(T)$, implying that

$$
\mathrm{p}_{\mathrm{j}} \mathrm{v}(\mathrm{m})+\left(1-\mathrm{p}_{\mathrm{j}}\right) \mathrm{v}(\mathrm{n})+\mathrm{z}\left(\mathrm{p}_{\mathrm{j}} \mathrm{r}_{\mathrm{j}}, \mathrm{m}, \mathrm{n}\right)=\mathrm{v}(\mathrm{s})+\mathrm{z}\left(1, \mathrm{r}_{\mathrm{j}}, \mathrm{m}, \mathrm{n}\right) .
$$

(Hereafter, we suppress the arguments $\mathrm{m}$ and $\mathrm{n}$ in $\mathrm{z}$, since they play no role.)

Consider individuals A and B with identical utility function (1). The trustworthiness reference point for $\mathrm{A}, \mathrm{r}_{\mathrm{a}}$ is greater than the trustworthiness reference point for $\mathrm{B}, \mathrm{r}_{\mathrm{b}}$. The critical assumption is that there is diminished importance for the reference when $\mathrm{p}=1$ (i,e., in lottery $\mathrm{S}$ ). Specifically, for all reference points $r_{a}>r_{b}$ and all probabilities of trustworthiness $p<1$,

$$
\mathrm{z}\left(1, \mathrm{r}_{\mathrm{b}}\right)-\mathrm{z}\left(1, \mathrm{r}_{\mathrm{a}}\right)<\mathrm{z}\left(\mathrm{p}, \mathrm{r}_{\mathrm{b}}\right)-\mathrm{z}\left(\mathrm{p}, \mathrm{r}_{\mathrm{a}}\right) .
$$

PROPOSITION. Given (3) and that $\mathrm{z}$ is increasing with $\mathrm{p}$, an individual with a higher value of reference trustworthiness, $r$, will require a greater level of trustworthiness, $p$, in order to trust. 
The Proof is given in the Appendix. In the context of our paper, the Proposition yields:

Implication 1. Gulf citizens will require a higher level of trustworthiness than Westerners before they trust.

To assess minimally required trustworthiness levels, $\mathrm{p}$, we have subjects play a modified trust game [Camerer and Weigelt 1988] in the two regions. The game is shown in Figure 1.

\section{Figure 1 about here}

We ask individuals (principals) what minimum acceptable probability of trustworthiness, $\mathrm{p}_{\mathrm{j}}$, would lead them to trust as opposed to receiving a sure payoff. The higher a principal's minimum acceptable probability value, the more she is willing to sacrifice in expected value to avoid trusting. The amount she is willing to pay is the difference in expected values from her Trust and Sure strategies if $\mathrm{p}_{\mathrm{j}}$ is just satisfied. Representing the expected trust payoff in brackets, that amount is $\left[\mathrm{p}_{\mathrm{j}} 15+\left(1-\mathrm{p}_{\mathrm{j}}\right) 8\right]-10$. Note, a principal's minimum acceptable probability value should be independent of her assessments of the probability of trustworthiness in the game. If the actual trustworthiness level is below her threshold value, she will end up not trusting; and if trustworthiness is above it, she will get the actual level and reap a surplus. Thus truthful revelation is optimal. ${ }^{4}$ Principals do not learn the true proportion of trustworthy agents in their game until after they have made their decisions. Moreover, the game offers no institutional protections. Thus, observed differences in behavior cannot be accounted for by cross-regional differences therein.

\footnotetext{
${ }^{4}$ Note that a principal cannot affect the probability she receives in the lottery, since it in no way relates to the answer that she provides. Given our procedure, truth-telling by a principal is as good as anything else. It is strictly dominant if, as seems reasonable, people believe that actual levels of trustworthiness may lie in the immediate neighborhood of their minimum acceptable probability, and if they obey the Substitution Axiom of von NeumannMorgenstern utility. Our procedure is closely related to the (strictly dominant) Becker-DeGroot-Marshak elicitation procedure. The major difference is that we do not draw our probability of payoff randomly from a uniform distribution, but rather observe it empirically.
} 
Willingness to trust is likely related to willingness to take risk. If people were accustomed to different levels of success when taking risk in the two regions, a similar logic would apply to willingness to take risk as to willingness to trust. Given that earning returns based on chance is strongly discouraged in Islamic Law, that gambling is strictly forbidden, and that Islamic banks tend to invest more conservatively then Western banks [Al-Suwailem 2000], there may well be cross-regional differences in success reference points leading to differences in willingness to take risk. In addition, there could also be differences in standard risk preferences.

To make sure we are not merely picking up cross-regional differences in willingness to take risk in our experiments, we ran a control treatment in each country, the risky dictator game [Bohnet and Zeckhauser 2004, Bohnet et al. 2008]. In it, Nature rather than the Agent determines the outcome. Figure 1 represents the risky dictator game. It is identical to the trust game except "Trust" is replaced with "Gamble," "Agent" is replaced with "Nature," and "Trustworthy" and "Betray" are respectively replaced with "Success" and "Failure." A comparison of behavior in the trust game and the risky dictator game will tell us whether cross-regional differences in willingness to trust are due to differences in betrayal intolerance, differences in risk intolerance or a combination of the two.

According to Implication 1, people in the West will trust for lower levels of trustworthiness than people in the Gulf. This also suggests that trust is more responsive to changes in the likelihood of trustworthiness in the West than in the Gulf. To examine, we compute the elasticity of trust. That elasticity tells how the percentage of those not trusting diminishes in response to a percentage reduction in those not trustworthy. Let $\alpha$ be the fraction of trusting principals, and $\beta$ the fraction of trustworthy agents. Our elasticity concept looks at the curve $x=f(\beta)$. The elasticity measure at each point is thus $[d \alpha /(1-\alpha)] /[d \beta /(1-\beta)]$. Since our data is 
limited, we compute this elasticity looking only at decile intervals. Thus, we measure the elasticity at each 10-percent increase of trustworthiness with start points at 0 to 90 percent. $^{5}$ To get an overall elasticity measure, we average these ten numbers.

Implication 2. Trust levels will be less elastic to levels of trustworthiness in the Gulf than in the West.

Given greater concern with levels of trustworthiness and lesser concern with monetary returns from trusting in the Gulf, Gulf citizens will respond less to changes in the cost of betrayal. We test this by comparing willingness to trust in a high-cost and a low-cost trust game. Implication 3. Trust levels will respond less to changes in the cost of betrayal in the Gulf than in the West.

\section{Design and Procedures}

As is traditional with experiments, we relied on student subjects, with 736 total subjects in the five countries. ${ }^{6}$ The students were from Kuwait University in Kuwait, Sultan Qaboos University in Oman, the University of Zurich in Switzerland, UAE University in the United Arab Emirates, and from various universities in the greater Boston area in the United States. Participants' average age and self-reported wealth levels on a scale from 1 (poor) to 6 (wealthy) were, respectively, 21 and 4.1 in Kuwait, 21 and 3.7 in Oman, 23 and 4.0 in Switzerland and 24

\footnotetext{
${ }^{5}$ We exclude 100 percent as everyone is willing to trust if trustworthiness is guaranteed. Thus, the elasticity in the final decile interval is always 1.

${ }^{6}$ As we are interested in comparisons between Gulf and Western countries, ideally we would have liked to run our experiments with representative samples of the general population in each country. However, this was not feasible in the three Gulf countries. To the best of our knowledge, not even Western surveys have been allowed to be conducted in any of the three countries to date (or any other Gulf country, for that matter). Our experiments represent five case studies. We do not claim that they are conclusive about behavior in either the Gulf or the West.
} 
and 3.5 in the United States. ${ }^{7}$ We ran a total of 28 experimental sessions; 22 to 36 subjects participated in each.

In Oman, Kuwait, Switzerland and the United States, we ran mixed-sex sessions. In the UAE, this was not possible since higher education is sex segregated; experiments there were conducted separately for female and male subjects. ${ }^{8}$ Subjects were identified by code numbers and kept anonymous to other players. They were randomly assigned to the role of principal or agent and randomly matched (single-blind). Table I provides an overview of the participants in our three sets of experiments, the baseline trust game, the risky dictator game, and a high-cost trust game. The high-cost trust game lowered the principal's payoff given betrayal to 6 and raised the agent's associated payoff to 24 points to determine how changes in the material cost of betrayal affected trust decisions. The probability that equates expected values in the first two games is 0.296 ; in the third (high-cost) game it is 0.444 .

\section{Table I about here}

The payoffs were presented to subjects in a matrix form with neutral terminology, and no discussion of breakeven probabilities. Payoffs were given in points. Each point was converted to respectively 0.25 Kuwaiti Dinar, 0.2 Omani Rial, 1 Swiss frank, 1 UAE dirham, or 1 USA dollar at the end of the experiment. Subjects earned a 10-point show up fee and received on average an additional 13 points for an experiment that took approximately 30-60 minutes. To ensure the

\footnotetext{
${ }^{7}$ We collected this information in a short post-experimental questionnaire. We were not allowed to collect demographic information in the UAE. However, as the sessions there were segregated by sex, we can control for a person's sex in all our analyses.

${ }^{8}$ To get a sense for how this might affect behavior, we added an all-male and an all-female session to our mixedsex session in Kuwait, a nation with substantial components of both single-sex and mixed-sex higher education. We believe that there are no analogous single-sex comparison groups in the West as people self-select into single-sex colleges in the West but not in the UAE.
} 
equivalence of experimental procedures across countries, we followed Roth et al. [1991] on designs for multinational experiments. ${ }^{9}$

The experiments were run as follows: In the trust games, we asked principals what minimum percentage of trustworthy behavior they would require to trust. The neutral language description was: "How large would the probability of being paired with a Person Y who chose option 1 minimally have to be for you to pick B over A?" (The agent's "option 1" is what we label "trustworthy." The principal's choice "B" is our "trust.") We used the strategy method for agents: Before they knew their principal's decision, we asked them whether or not they would reward trust were it offered. Specifically, we asked: "Which option, 1 or 2, do you choose in case B?" If a principal's minimum acceptable probability exceeded the percentage of trustworthy agents in a given session, $\mathrm{p}^{*}$, both principal and agent earned the sure payoff. If a principal's minimum acceptable probability was equal to or lower than $\mathrm{p}^{*}$, the two payoffs were determined by the agent's choice. Principals were informed on the whole procedure, including that agents' decisions would be used to calculate $\mathrm{p}^{*}$. Agents were not informed that principals were asked to state their minimum acceptable probability of trustworthiness, nor that we would calculate a p*, since we did not want our elicitation procedure to affect agents' decisions.

In the risky dictator game, the principal becomes the "dictator;" the agent is a "recipient," with no active role to play, as in the standard dictator game [Kahneman et al. 1986]. We asked principals to indicate their minimum acceptable probability of earning 15 such that they would take the gamble rather than the sure outcome: "How large would the probability of receiving

\footnotetext{
${ }^{9} \mathrm{We}$ controlled for currency, language and experimenter effects to the best of our ability. To produce parity in rewards across the five nations, we used the most direct measure of opportunity cost of time we could find as a guideline, the hourly wage of an undergraduate research assistant. We had the instructions translated (and backtranslated) from English to Arabic. The experiments were conducted by the first two listed authors. They first ran experiments in the US before conducting sessions in other countries. We did not find any evidence for experimenter effects in the US. The first author ran the experiments in Switzerland and the UAE, and the second author ran the experiments in Kuwait and Oman. The instructions are available from the authors upon request.
} 
option 1 minimally have to be for you to pick B over A?" They were informed that $\mathrm{p}^{*}$ had been predetermined and was inside the envelope visibly posted to the blackboard. The average likelihood of trustworthiness from the baseline trust games in a given country served as $\mathrm{p}^{*}$ for the risky dictator games, which were conducted with different subjects after the trust games. If a principal's minimum acceptable probability was higher than the predetermined probability, $\mathrm{p}^{*}$, they were taken to reject the gamble. They were then paid the sure payoff. If their minimum acceptable probability was less than or equal to $\mathrm{p}^{*}$, we conducted the lottery by drawing a ball from an urn containing $\mathrm{p}^{*}$ good and (1-p*) bad balls. This determined whether principals received the 15 or the 8 payment; the complementary 15 or 22 payment went to their recipient.

Before subjects made their decision, they had to complete a quiz testing their understanding. Only after all subjects understood the problem and could calculate their earnings for different values of hypothetical $\mathrm{p}_{\mathrm{j}}$ and $\mathrm{p}^{*}$ did we proceed with the experimental decisions. After subjects had made their decisions, and had given us the demographic information we were allowed to collect, we informed everyone on the details of the experimental procedure and the results. Subjects presented their code number to collect a sealed envelope with their earnings.

\section{Results}

We first examine Implication 1 from our Proposition, namely that people in the Gulf will require higher levels of trustworthiness before trusting than Westerners. We then compare required trustworthiness levels with required success levels in the risky dictator game to make sure behavior in the trust game is not just due to people's willingness to take risk. Finally, we report results for Implications 2 and 3, namely, how responsive people are to changes in the likelihood or the cost of betrayal. Table II summarizes principals' willingness to trust.

\section{Table II about here}


On average, people in the Gulf countries are willing to trust if at least 70 percent of the people are trustworthy while people in the Western countries are willing to trust if at least 52 percent of the people are trustworthy. This cross-regional difference is significant ${ }^{10}$ for each cross-regional country comparison. Emiratis, Kuwaitis and Omanis require significantly higher levels of trustworthiness before trusting than do Swiss and Americans. This affirms Implication 1. Table III reports a simple regression with the minimum acceptable probability as the dependent variable. In Columns 1 and 2 we group the countries by region $(\mathrm{Gulf}=1)$ and control for sex $($ woman $=1)$, the sex composition of our sessions $($ mixed $=1)$, and the possible interaction variables. Principals in the Gulf countries require higher minimum acceptable probabilities than Western principals. Columns 3 to 5 treat each country separately, with the United States the excluded group. Minimum acceptable probabilities do not differ between Switzerland and the United States, and the cross-regional difference in minimum acceptable probabilities is due to both sexes in the Emirates and Oman, but only to men in Kuwait. Kuwaiti women request probability thresholds on a par with their Western counterparts. ${ }^{11}$

\section{Table III about here}

To determine whether people's willingness to trust reflects primarily their willingness to take risk, we compare the probability thresholds for trusting (Table II) with the thresholds for risk-taking. Table IV presents principals' minimum acceptable probabilities in the risky dictator game in the five countries. We find that the mean minimum acceptable probabilities in the trust game significantly exceed those of the risky dictator game in all countries, namely by 0.16 in Kuwait, 0.26 in Oman, 0.33 in the UAE, 0.11 in Switzerland and 0.22 in the United States (with

\footnotetext{
${ }^{10}$ We run one-tailed Mann-Whitney $\mathrm{U}$ tests for differences in means. All p-values reported are based on this test, unless noted otherwise. A difference is reported as significant if $p<0.05$.

${ }^{11}$ Kuwait ranks highest on the gender-related development index in the Arab world [Table 3, AHDR 2004]. On May 16, 2005, the Kuwaiti parliament voted to give women the right to vote and to run for political office.
} 
$\mathrm{p}<0.05$ everywhere except $\mathrm{p}<0.1$ in Switzerland). This implies that all subjects thought it worse to lose the high payment due to betrayal than due to an unlucky draw on a chance device i.e., were intolerant to betrayal.

\section{Table IV about here}

On average, people in the Gulf are willing to take risk if the likelihood of getting the good outcome is at least 46 percent while their counterparts in the West are willing to do so for a minimum acceptable probability of at least 36 percent. This cross-regional difference is mainly driven by men. Repeating the analysis conducted for the trust game (comparisons of means using Mann-Whitney tests and regressions), we find that Gulf men are significantly less willing to take risk than Western men while there are no cross-regional differences in risk-taking for women.

Overall, the cross-regional difference in willingness to trust is mainly due to differences in intolerance to betrayal. This supports our notion that trust behavior responds to differences in trustworthiness reference points across the regions. In addition, for men, there are also crossregional differences in willingness to take risk.

To see how responsive willingness to trust is to changes in the likelihood of betrayal, Figure II shows the percentage of principals willing to trust for given likelihoods of trustworthiness in the two regions.

\section{Figure II about here}

Emiratis, Kuwaitis and Omanis' willingness to trust is less elastic to changes in the likelihood of trustworthiness than that of Westerners. Our elasticity measure indicates how on average the percentage of those not trusting responds to a percentage reduction in those not trustworthy for each 10-percent change in trustworthiness. Table $\mathrm{V}$ presents the results, with the UAE at the bottom and Switzerland at the top. This supports Implication 2. 


\section{Table V about here}

To examine how responsive willingness to trust is to changes in the cost of betrayal, we compare the required trustworthiness thresholds in the basic trust game and the high-cost trust game in Oman and the United States (the only two countries studied). We find a similar pattern as above. Americans respond to changes in the material cost of betrayal, Omanis do not. Table VI presents principal's minimum acceptable probability values for the two games in the two countries. Americans request significantly higher minimum acceptable probabilities in the highcost than in the baseline trust game. Omanis' minimum acceptable probabilities, by contrast, differ hardly at all across the two conditions. ${ }^{12}$ This supports Implication 3.

\section{Table VI about here}

Our major interest is why and when people trust strangers, hence our focus on the behavior of principals. But agents' responses are interesting as well, although they do not entail any information on cross-regional differences in accustomed levels of trustworthiness. In our experiments, betrayal entails neither reputational nor legal costs - prime concerns respectively in the Gulf and the West - and thus primarily reflect a person's intrinsic motivation to be trustworthy. There are no significant cross-regional differences in our agents' willingness to reward trust. In our baseline trust game, 43 percent of the agents chose to reward trust in Kuwait $(\mathrm{N}=39), 31$ percent in Oman $(\mathrm{N}=29), 32$ percent in the United Arab Emirates $(\mathrm{N}=28), 28$ percent in Switzerland $(\mathrm{N}=25)$ and 29 percent in the United States $(\mathrm{N}=31){ }^{13}$

\footnotetext{
${ }^{12}$ The trustworthiness rates in the high-cost trust games - not relevant for the probability thresholds-are alike in the two countries: 36 percent are trustworthy in the US $(\mathrm{N}=36)$ and 37 percent in Oman $(\mathrm{N}=35)$. .

${ }^{13}$ None of the differences between these percentages is significant (e.g., chi ${ }^{2}$-test $\mathrm{p}=0.21$ when comparing Kuwait and Switzerland, the two extremes). Calculating weighted averages for each region gives us a trustworthiness rate of 37 percent in the three Gulf and 29 percent in the two Western countries $\left(\mathrm{chi}^{2}\right.$-test $\left.\mathrm{p}=0.32\right)$.
} 


\section{Conclusion}

Private investment levels and trust levels are lower in Gulf than in Western countries. This paper shows that differences in accustomed levels of trustworthiness might contribute to this pattern, leading people in the Gulf to require higher levels of trustworthiness before trusting than Westerners. In the Gulf, trust has traditionally been primarily produced by relying on personal relationships while in the West formal rules, such as contract law, play an important role. Relation-based trust decreases the likelihood of betrayal; rule-based trust decreases the cost of betrayal. Thus, the reference points for trustworthiness are higher in the Gulf than in the West.

Following Köszegi-Rabin [2006], we posited a gain-loss utility for accepting a level of trustworthiness below one's reference level. This utility adds to the pure von NeumannMorgenstern utility from the game's monetary payoffs. Given their higher trustworthiness reference points, people in the Gulf should be willing to pay a higher price to avoid trusting than people in the West. Our experiments confirmed this prediction. Emiratis, Kuwaitis and Omanis demanded a substantially higher minimum trustworthiness threshold before trusting than did the Americans and Swiss, well exceeding the probability thresholds required to take risk in an analogous game, where Nature determined the outcome. Cross-regional differences in willingness to trust mainly came from differences in people's intolerance of betrayal, though for men differences in willingness to take risk also contributed.

Differences in trust preferences, brought about by differences in the reference points for trustworthiness for the two regions, help us understand disparities in private investment rates. Beyond trust levels, a better understanding of preferences that depend on reference points may prove particularly useful when comparing countries or cultures. 


\section{APPENDIX}

Define $\mathrm{p}_{\mathrm{a}}$ and $\mathrm{p}_{\mathrm{b}}$ to be the minimum levels of trustworthiness such that $\mathrm{A}$ and $\mathrm{B}$ respectively select Trust. We show that at trustworthiness level $\mathrm{p}_{\mathrm{b}}$, A does not select Trust, implying that the $\mathrm{p}_{\mathrm{a}}>\mathrm{p}_{\mathrm{b}}$. Set $\mathrm{p}=\mathrm{p}_{\mathrm{b}}$ for individual $\mathrm{A}$. Then by (3)

$$
\mathrm{z}\left(1, \mathrm{r}_{\mathrm{b}}\right)-\mathrm{z}\left(1, \mathrm{r}_{\mathrm{a}}\right)<\mathrm{z}\left(\mathrm{p}_{\mathrm{b}}, \mathrm{r}_{\mathrm{b}}\right)-\mathrm{z}\left(\mathrm{p}_{\mathrm{b}}, \mathrm{r}_{\mathrm{a}}\right)
$$

Rearranging terms yields $\mathrm{z}\left(1, \mathrm{r}_{\mathrm{b}}\right)-\mathrm{z}\left(\mathrm{p}_{\mathrm{b}}, \mathrm{r}_{\mathrm{b}}\right)<\mathrm{z}\left(1, \mathrm{r}_{\mathrm{a}}\right)-\mathrm{z}\left(\mathrm{p}_{\mathrm{b}}, \mathrm{r}_{\mathrm{a}}\right)$. Furthermore, (2) implies that

$$
\mathrm{p}_{\mathrm{b}} \mathrm{v}(\mathrm{x})+\left(1-\mathrm{p}_{\mathrm{b}}\right) \mathrm{v}(\mathrm{y})+\mathrm{z}\left(\mathrm{p}_{\mathrm{b}}, \mathrm{r}_{\mathrm{b}}\right)=\mathrm{v}(\mathrm{s})+\mathrm{z}(1, \mathrm{rb})
$$

Substituting terms in (4) and (5) yields

$$
\mathrm{p}_{\mathrm{b}} \mathrm{v}(\mathrm{x})+\left(1-\mathrm{p}_{\mathrm{b}}\right) \mathrm{v}(\mathrm{y})+\mathrm{z}\left(\mathrm{p}_{\mathrm{b}}, \mathrm{r}_{\mathrm{a}}\right)<\mathrm{v}(\mathrm{s})+\mathrm{z}\left(1, \mathrm{r}_{\mathrm{a}}\right)
$$

The LHS of (6) is simply the utility of Trust for A at trustworthiness level $\mathrm{p}_{\mathrm{b}}$, and the RHS is A's utility of Sure. This inequality implies that at $\mathrm{p}_{\mathrm{b}}$ A does not select Trust. Since the sum of the VN-M terms and $\mathrm{z}$ are both increasing with $\mathrm{p}$, and that at $\mathrm{p}=1 \mathrm{~A}$ does trust, there must a value $\mathrm{p}_{\mathrm{a}}$ $>\mathrm{p}_{\mathrm{b}}$ that gets A to trust. QED.

Note, we have not required the stronger condition of continuity of $\mathrm{z}$ in its arguments, and only require (3) to hold when $\mathrm{p}=1$ for the Sure lottery. Had we assumed continuity and differentiability, a sufficient condition replacing (3) would be that $\partial^{2} \mathrm{z} / \partial \mathrm{r} \partial \mathrm{p}>0$.

In the context of our paper, the Proposition implies that Gulf citizens will require a higher level of trustworthiness than Westerners to Trust. 
TABLE I: Numbers of Participants in the Different Subject Pools

\begin{tabular}{lccc}
\hline & Mixed & All Men & All Women \\
\hline Baseline Trust Game & 24 & 26 & 28 \\
Kuwait & 58 & 28 & 28 \\
Oman & 50 & & \\
United Arab Emirates & 62 & & \\
Switzerland & & & \\
United States & 32 & 28 & 20 \\
Risky Dictator Game & 44 & 30 & 30 \\
Kuwait & 48 & & \\
Oman & 58 & & \\
United Arab Emirates & & & \\
Switzerland & 70 & & \\
United States & 72 & & \\
High-cost Trust Game & & \\
Oman & & \\
United States & &
\end{tabular}

TABLE II: Minimum acceptable probabilities in Baseline Trust Game Mean, Median, [N]

\begin{tabular}{lccc}
\hline & All & Men & Women \\
\hline Kuwait $^{14}$ & $\mathbf{0 . 6 1}$ & $\mathbf{0 . 7 4}$ & $\mathbf{0 . 5 3}$ \\
& 0.70 & 0.80 & 0.50 \\
Oman & {$[39]$} & {$[15]$} & {$[24]$} \\
& $\mathbf{0 . 7 2}$ & $\mathbf{0 . 7 2}$ & $\mathbf{0 . 7 3}$ \\
& 0.80 & 0.70 & 0.80 \\
United Arab & {$[29]$} & {$[12]$} & {$[16]$} \\
Emirates & $\mathbf{0 . 8 1}$ & $\mathbf{0 . 7 7}$ & $\mathbf{0 . 8 6}$ \\
& 0.80 & 0.80 & 0.95 \\
Switzerland & {$[28]$} & {$[14]$} & {$[14]$} \\
& $\mathbf{0 . 5 1}$ & $\mathbf{0 . 4 6}$ & $\mathbf{0 . 6 2}$ \\
& 0.55 & 0.48 & 0.60 \\
United States & {$[25]$} & {$[18]$} & {$[7]$} \\
& $\mathbf{0 . 5 4}$ & $\mathbf{0 . 5 0}$ & $\mathbf{0 . 6 1}$ \\
& 0.50 & 0.50 & 0.72 \\
& {$[31]$} & {$[19]$} & {$[12]$} \\
\hline
\end{tabular}


TABLE III: Determinants of minimum acceptable probabilities in the Baseline Trust Game

\begin{tabular}{|c|c|c|c|c|c|}
\hline & $(1)$ & (2) & (3) & (4) & $(5)$ \\
\hline Gulf countries & $\begin{array}{c}0.175 * * \\
(0.041)\end{array}$ & $\begin{array}{c}0.249 * * \\
(0.075)\end{array}$ & & & \\
\hline Kuwait & & & $\begin{array}{c}0.065 \\
(0.056)\end{array}$ & $\begin{array}{c}0.063 \\
(0.057)\end{array}$ & $\begin{array}{c}0.243 * * \\
(0.079)\end{array}$ \\
\hline Oman & & & $\begin{array}{c}0.179 * * \\
(0.060)\end{array}$ & $\begin{array}{c}0.176^{* * *} \\
(0.062)\end{array}$ & $\begin{array}{l}0.217^{*} \\
(0.084)\end{array}$ \\
\hline Switzerland & & & $\begin{array}{c}0.036 \\
(0.063)\end{array}$ & $\begin{array}{c}0.035 \\
(0.063)\end{array}$ & $\begin{array}{c}0.034 \\
(0.075)\end{array}$ \\
\hline UAE & & & $\begin{array}{c}0.269 * * \\
(0.061)\end{array}$ & $\begin{array}{c}0.268 * * \\
(0.062)\end{array}$ & $\begin{array}{c}0.270 * * \\
(0.080)\end{array}$ \\
\hline Women & & $\begin{array}{c}0.095 \\
(0.123)\end{array}$ & & $\begin{array}{c}0.009 \\
(0.040)\end{array}$ & $\begin{array}{c}0.116 \\
(0.084)\end{array}$ \\
\hline Mixed session & & $\begin{array}{l}-0.018 \\
(0.079)\end{array}$ & & & \\
\hline Gulf countries*Women & & $\begin{array}{l}-0.183^{\wedge} \\
(0.105)\end{array}$ & & & \\
\hline Women*Mixed session & & $\begin{array}{c}0.039 \\
(0.103)\end{array}$ & & & \\
\hline Kuwait*Women & & & & & $\begin{array}{c}-0.332^{* *} \\
(0.113)\end{array}$ \\
\hline Oman*Women & & & & & $\begin{array}{l}-0.105 \\
(0.121)\end{array}$ \\
\hline Switzerland*Women & & & & & $\begin{array}{c}0.037 \\
(0.132)\end{array}$ \\
\hline UAE*Women & & & & & $\begin{array}{l}-0.027 \\
(0.120)\end{array}$ \\
\hline Constant & $\begin{array}{c}0.527 * * \\
(0.032)\end{array}$ & $\begin{array}{c}0.500 * * \\
(0.089)\end{array}$ & $\begin{array}{c}0.543 * * \\
(0.042)\end{array}$ & $\begin{array}{c}0.539 * * \\
(0.045)\end{array}$ & $\begin{array}{c}0.498 * * \\
(0.052)\end{array}$ \\
\hline Observations & 152 & 151 & 152 & 151 & 151 \\
\hline R-squared & 0.11 & 0.15 & 0.18 & 0.18 & 0.25 \\
\hline
\end{tabular}

Standard errors in parentheses, $\wedge$ significant at $10 \% ; *$ significant at $5 \% ; * *$ significant at $1 \%$

\footnotetext{
${ }^{14}$ There are no significant differences in same-sex and mixed-sex sessions for either men or women. Men's behavior varies not at all; women are slightly though not significantly more willing to trust in same-sex than in mixed-sex sessions.
} 
TABLE IV: Minimum acceptable probabilities in Risky Dictator Game Mean, Median, [N]

\begin{tabular}{lccc}
\hline \hline & All & Men & Women \\
\hline Kuwait & $\mathbf{0 . 4 4}$ & $\mathbf{0 . 4 6}$ & $\mathbf{0 . 4 0}$ \\
& 0.42 & 0.43 & 0.27 \\
Oman & {$[40]$} & {$[25]$} & {$[15]$} \\
& $\mathbf{0 . 4 7}$ & $\mathbf{0 . 4 9}$ & $\mathbf{0 . 4 3}$ \\
United Arab Emirates & 0.45 & 0.48 & 0.40 \\
& {$[22]$} & {$[8]$} & {$[13]$} \\
Switzerland & $\mathbf{0 . 4 8}$ & $\mathbf{0 . 5 1}$ & $\mathbf{0 . 4 6}$ \\
& 0.48 & 0.50 & 0.45 \\
United States & {$[30]$} & {$[15]$} & {$[15]$} \\
& $\mathbf{0 . 4 0}$ & $\mathbf{0 . 3 3}$ & $\mathbf{0 . 4 8}$ \\
& 0.42 & 0.30 & 0.50 \\
& {$[24]$} & {$[13]$} & {$[11]$} \\
& $\mathbf{0 . 3 2}$ & $\mathbf{0 . 2 8}$ & $\mathbf{0 . 3 8}$ \\
& 0.29 & 0.29 & 0.35 \\
& {$[29]$} & {$[16]$} & {$[13]$} \\
\hline
\end{tabular}

TABLE V: Elasticity of Trust to the Likelihood of Trustworthiness

\begin{tabular}{lc}
\hline & Elasticity of Trust \\
\hline Kuwait & 0.81 \\
Oman & 0.57 \\
UAE & 0.21 \\
Switzerland & 1.17 \\
USA & 1.03 \\
\hline
\end{tabular}

TABLE VI: Minimum acceptable probabilities in Baseline and High-cost Trust Games Mean, Median, [N]

\begin{tabular}{lcccc}
\hline \hline & All & All & Men & Women \\
& Baseline & High-cost & High-cost & High-cost \\
\hline Oman & $\mathbf{0 . 7 2}$ & $\mathbf{0 . 7 1}$ & $\mathbf{0 . 7 2}$ & $\mathbf{0 . 6 8}$ \\
& 0.80 & 0.75 & 0.75 & 0.78 \\
United States & {$[29]$} & {$[35]$} & {$[23]$} & {$[12]$} \\
& $\mathbf{0 . 5 4}$ & $\mathbf{0 . 6 9}$ & $\mathbf{0 . 6 0}$ & $\mathbf{0 . 7 7}$ \\
& 0.50 & 0.75 & 0.70 & 0.80 \\
& {$[31]$} & {$[36]$} & {$[16]$} & {$[18]$} \\
\hline
\end{tabular}


Trustworthy

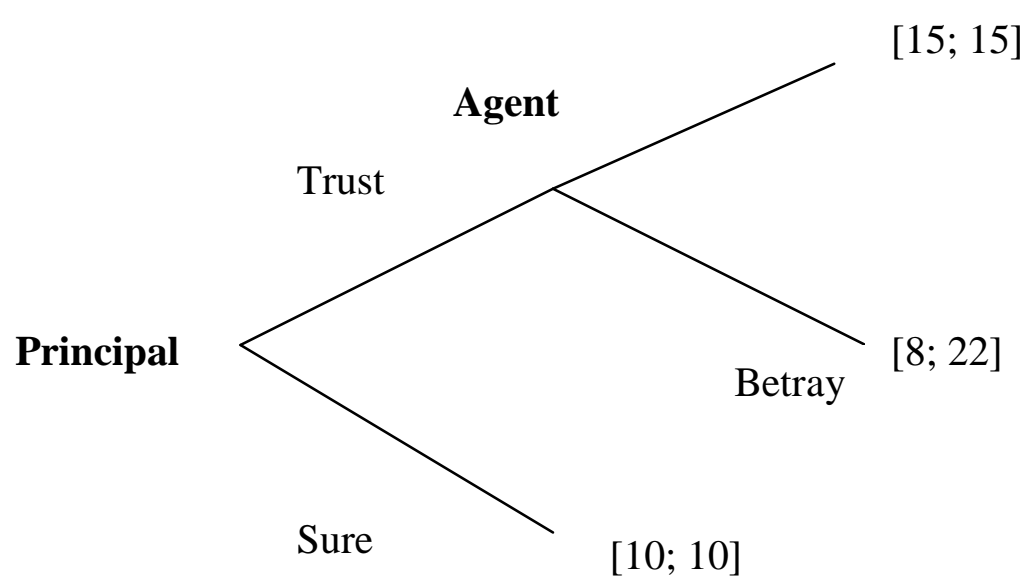

FIGURE I: The Trust Game

[Payoffs to Principal; payoffs to Agent]

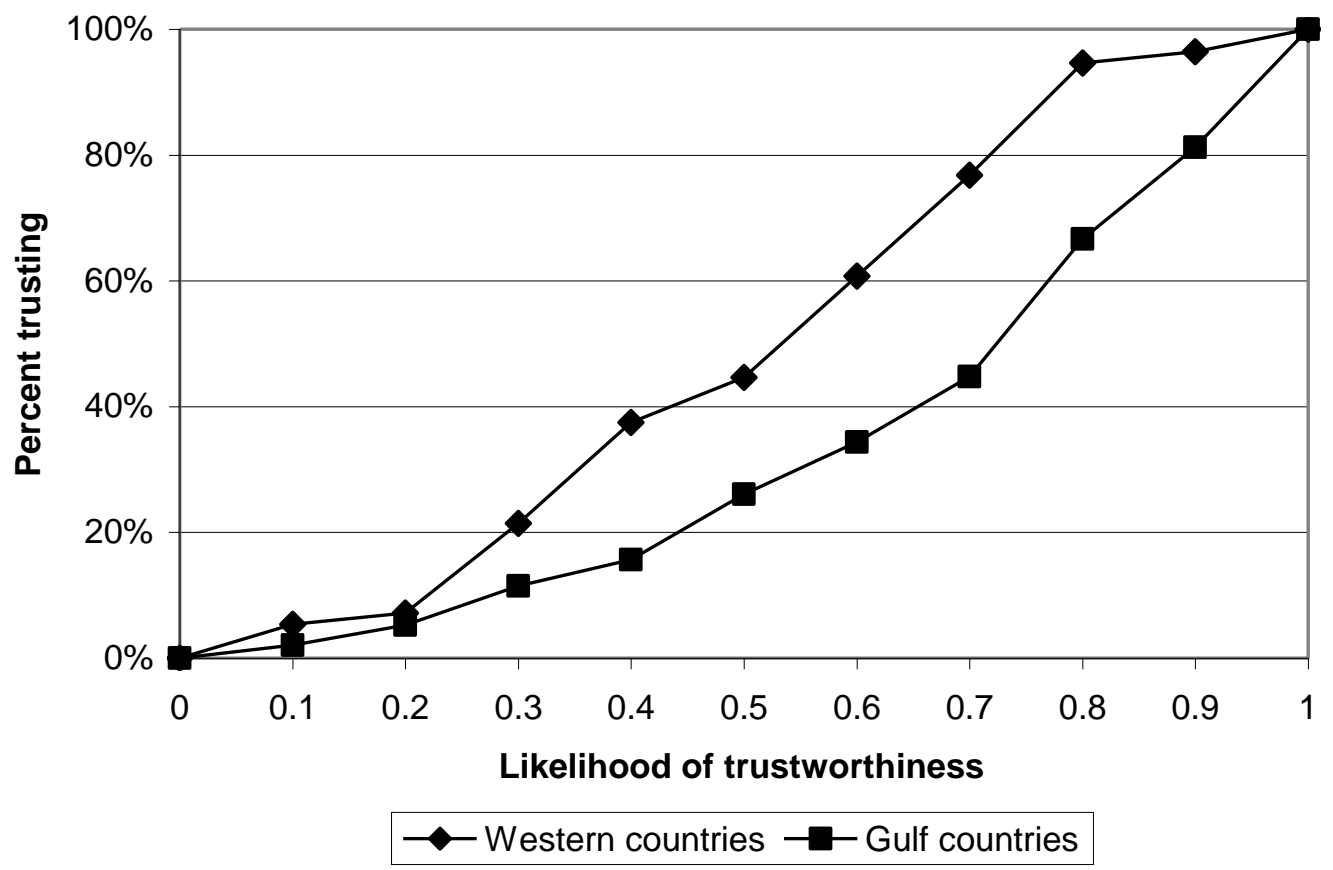

FIGURE II: Cumulative Distribution of Willingness to Trust in the West and in the Gulf 


\section{REFERENCES}

Al-Suwailem, Sami, “Decision Under Uncertainty: An Islamic Perspective,” Working Paper, AlRajhi Banking and Investment Corporation, Riyadh, Saudi Arabia, 2000.

Arab Human Development Reports (AHDR), United Nations Development Program, 2002-2004.

Bill, James A. and Robert Springborg, Politics in the Middle East (New York: Longman, 2000).

Bohnet, Iris and Richard Zeckhauser, "Trust, Risk and Betrayal,” Journal of Economic Behavior and Organization, LV (2004), 467-484.

Bohnet, Iris, Fiona Greig, Benedikt Herrmann and Richard Zeckhauser, "Betrayal Aversion," American Economic Review, XCVIII (2008), 294-310.

Camerer, Colin and Keith Weigelt, "Experimental Tests of a Sequential Equilibrium Reputation Model," Econometrica, LVI (1988), 1-36.

Economist, “A Long Way to Go,” April 9, 2005, 36-38.

Greif, Avner, "Cultural Beliefs and the Organization of Society: A Historical and Theoretical Reflection on Collectivist and Individualist Societies," Journal of Political Economy, CII (1994), 912-950.

Hofstede, Geert, Culture's Consequences, $2^{\text {nd }}$ edition (Thousand Oaks, CA: Sage, 2001).

Inglehart, Ronald F., Mansoor Moaddel and Mark Tessler, "Xenophobia and In-Group Solidarity in Iraq: A Natural Experiment on the Impact of Insecurity," Perspectives on Politics IV (2006), 495-505.

Inglehart, Ronald F., “The Worldviews of Islamic Publics in Global Perspective,” in M. Moaddel, ed., Values and Perception of Islamic and Middle Eastern Publics: Findings of Value Surveys, (New York: Palgrave 2007), pp. 25-46. 
Kahneman, Daniel, Jack L. Knetsch and Richard H. Thaler, "Fairness and the Assumptions of Economics,” Journal of Business LIX (1986), 285-300.

Kahneman, Daniel and Amos Tversky, "Prospect theory: An analysis of decisions under risk," Econometrica, XLVII (1979), 263-291.

Knack, Stephen and Philip Keefer, “Does Social Capital Have an Economic Payoff?” Quarterly Journal of Economics, CXII (1997), 1251-1288.

Köszegi, Botond and Matthew Rabin, “A Model of Reference-Dependent Preferences,” Quarterly Journal of Economics, CXXI (2006), 1133-1165.

Köszegi, Botond and Matthew Rabin, "Reference-Dependent Risk Attitudes," American Economic Review, XCVII (2007), 1047-1073.

Kuran, Timur, Islam and Mammon (Princeton, NJ: Princeton University Press, 2004).

Rosen, Lawrence, The Justice of Islam (Oxford: Oxford University Press, 2000).

Roth, Alvin E., Vesna Prasnikar, Masahiro Okuno-Fujiwara, and Shmuel Zamir, "Bargaining and Market Behavior in Jerusalem, Ljubliana, Pittsburgh, and Tokyo: An Experimental Study," American Economic Review, LXXXI (1991), 1068-95.

Sala-i-Martin, Xavier and Elsa V. Artadi, "Economic Growth and Investment in the Arab World," Working paper, Columbia University, 2002.

Triandis, Harry C., Individualism and Collectivism (Boulder, CO: Westview Press, 1995).

Vogel, Frank E., "The Contract Law of Islam and of the Arab Middle East,” Working Paper, Harvard Law School, 1997. 


\section{* Harvard University}

** University of Nottingham 